\title{
Influence of Soil, Vegetation, and Grazing Management on Infiltration Rate and Sediment Production of Edwards Plateau Rangeland
}

\author{
W. ALLAN McGINTY, FRED E. SMEINS AND LEO B. MERRILL
}

\section{Abstract}

Terminal infiltration rates for one pasture in a 4-pasture deferred-rotation grazing system and a 27-year exclosure were found to be similar $(10.40$ and $10.24 \mathrm{~cm} / \mathrm{hr}$, respectively). A heavily, continuously grazed pasture exhibited less than one-half the infiltration rate $(4.41 \mathrm{~cm} / \mathrm{hr})$ of the rotation pasture and exclosure. Grazed pastures were stocked at approximately the same rate $(5.0 \mathrm{ha} / \mathrm{AU} / \mathrm{yr})$. The continuously grazed pasture also had greater sediment loss $(211 \mathrm{~kg} / \mathrm{ha})$ than the rotation pasture and exclosure $(134$ and $160 \mathrm{~kg} / \mathrm{ha}$, respectively). Infiltration rate and sediment production were significantly influenced by plant biomass, bulk density, depression storage, and soil depth.

Soil and vegetation influences on infiltration and sediment production of rangeland have been documented (Coleman 1953; Branson et al. 1972). Grazing influences infiltration and erosion primarily through its impact on soil and vegetation. Overgrazing generally decreases infiltration (Rhoades et al. 1964; Rauzi and Hanson 1966; Lusby 1970) and causes an increase in erosion (Dunford 1949; Johnston 1962).

Although effects of different intensities and durations of continuous grazing on infiltration and sediment production have been studied, there is a lack of information on the effects of rotational grazing on the hydrologic condition of rangeland. There have been few infiltration studies of any type in Texas, and no published data exists for the Edwards Plateau relative to the influence of soil or grazing management on infiltration and sediment production. The purpose of this study was to evaluate edaphic variables, vegetation and grazing management as they influence infiltration rate and sediment production of Edwards Plateau rangeland.

\section{Study Area}

The study was conducted on the 1,430-ha Texas A\&M University Agricultural Research Station, which is located $56 \mathrm{~km}$ south of Sonora, Texas, within the Edwards Plateau Land Resource Area (Godfrey et al. 1970). Mean July temperature is $30^{\circ} \mathrm{C}$; mean January temperature is $9^{\circ} \mathrm{C}$ (Hardy et al. 1962). Mean annual rainfall at the Station is $57.2 \mathrm{~cm}$. May and September are the wettest months and average 7.8 and $7.6 \mathrm{~cm}$, respectively (Long 1962).

Authors are, respectively, graduate research assistant and associate professor, Depart ment of Kange Science, Iexas A\&M University, College Station; and protessor, Texas A\&M University Agricultural Research Station, Sonora.

This report is published with approval of the Director, Texas Agricultural Experiment Station, as TA-14,485.

The authors wish to acknowledge the Office of Water Research and Technology (Project (-6.310) for financial support. Dr. W. H. Blackburn for assistance in construction and use of the drip infiltrometer. and personnel of the Sonora Research Station for their field assistance.

Manuscript received Junc 3, 1978
Dominant soils are Tarrant stony clays (Lithic Haplustolls) which are grayish brown and 15 to $30 \mathrm{~cm}$ deep. They contain large amounts of limestone fragments, stones and gravel, and are underlain by a hard limestone substratum that is usually fractured and porous. These soils occupy level divides and sloping areas adjacent to small streams (Carter et al. 1938). Slopes vary from 0 to $8 \%$. Tarrant silty clays also occur; they are deeper soils and have fewer limestone fragments and stones.

The area is characterized by mid and short grasses with varying densities of woody plants scattered singly or in clumps throughout the grassland. Dominant herbaceous plants include common curlymesquite (Hilaria belangeri), threeawn (Aristida spp.) and sideoats grama (Bouteloua curtipendula). Important woody plants include vasey shin oak (Quercus pungens var. vaseyana), live oak (Quercus virginiana), honey mesquite (Prosopis glandulosa var. glandulosa), ashe juniper (Juniperus ashei), and redberry juniper (Juniperus pinchoti) (Smeins et al. 1975).

\section{Methods}

Two grazed pastures (each $32 \mathrm{ha}$ ) and an ungrazed exclosure ( $16 \mathrm{ha}$ ) were selected for study. One pasture has been heavily stocked ( 4.6 to $5.4 \mathrm{ha} / \mathrm{AU}$ ) and continuously grazed (heavy continuous pasture) for the past 27 years with a 60-20-20 AU ratio of cattle, sheep, and goats, respectively. Herbaceous vegetation was dominated by common curlymesquite with lesser amounts of threeawns and red grama (Bouteloua trifida). Total standing herbaceous biomass averaged $1,270 \mathrm{~kg} / \mathrm{ha}$ and litter $1,188 \mathrm{~kg} / \mathrm{ha}$ in June, 1976. Soil depth varied from 3 to $60 \mathrm{~cm}$ and slope ranged from 0 to $4 \%$.

Another pasture, under the Merrill iour pasture, three herd, deferred-rotation system (4-pasture system) (Merrill 1954) since 1969 , was stocked at $5.2 \mathrm{ha} / \mathrm{AU}$ with a $60-20-20 \mathrm{AU}$ ratio of cattle, sheep, and goats, respectively. It was grazed continuously from 1949 to 1969 with cattle and goats at a moderate rate of $16.2 \mathrm{ha} / \mathrm{AU}$. Herbaceous vegetation was dominated by common curlymesquite with lesser amounts of threeawns, sideoats grama, and cane bluestem (Bothriochloa barbinodes). Total standing herbaccous biomass averaged $2,200 \mathrm{~kg} / \mathrm{ha}$ and litter $2,700 \mathrm{~kg} / \mathrm{ha}$ in June, 1976 . Soil depth and slope were similar to the heavy continuous pasture.

The exclosure has been protected from livestock grazing for the past 28 years, but wildlife, primarily white-tailed deer (Odocoileus virginianus), had access to the area. Dominant grasses were common curlymesquite, cane bluestem, sideoats grama, and threeawns. Total standing herbaceous biomass averaged $2,000 \mathrm{~kg} / \mathrm{ha}$ and litter 3,000 $\mathrm{kg} / \mathrm{ha}$ in July, 1976. Soil depth and slope were similar to those of the other two pastures.

Soil depth was variable within each of the pastures. Thus, sites were selected within each pasture that represented shallow, intermediate, and deep soils. Means and standard deviations of soil depths in these sites were $20 \pm 8.9 \mathrm{~cm}, 31.5 \pm 9.3 \mathrm{~cm}$, and $47.3 \pm 13.4 \mathrm{~cm}$, respectively. During August, 1975, six soil samples were randomly collec- 
ted from the upper $5 \mathrm{~cm}$ of each site using a 156-cc core. Bulk density, particle density, pore space (Vormocil 1965), soil texture (Day 1956), and aggregate stability (Ashcroft 1954) were analyzed for these samples. Soil organic matter was determined by the Wakley-Black and loss on ignition $\left(24 \mathrm{hr}\right.$ at $430^{\circ} \mathrm{C}$ ) methods (Broadbent 1965; Davies 1974).

Infiltration rate, sediment production, vegetation biomass, and soil moisture were examined on 14 randomly selected, variable-sized plots (Blackburn et al. 1974) within each site in each pasture during the summer of 1976. A meter-square grid, divided into $0.01 \mathrm{~m}^{2}$ segments, was placed over each plot to determine its area. Areas varied from 0.35 to $0.45 \mathrm{~m}^{2}$

Infiltration rates were determined with a mobile drip infiltrometer (Blackburn et al. 1974). An application rate of $15.25 \mathrm{~cm} / \mathrm{hr}$ was used to insure that infiltration rate was exceeded on all plots. Plots were initially sprinkled to constitute a dry run (soil moisture at antecedent levels). After each dry run the plots were covered with plastic and 24 hr later were resprinkled with soil moisture at field capacity to constitute a wet run. Infiltration rates were measured as the difference between application rate and measured runoff rate. Runoff was pumped from the plots into 19 liter plastic bottles and measured gravimetrically at 5-min intervals. Infiltration runs lasted for $1 \mathrm{hr}$ on all dry runs to insure comparable soil moisture among all plots for the wet runs. Wet runs lasted for $1 \mathrm{hr}$, or until terminal infiltration rate was reached.

Before each infiltration run a soil sample of the upper $5 \mathrm{~cm}$ was taken outside each plot frame and the soil was oven-dried at $105^{\circ} \mathrm{C}$ for $24 \mathrm{hr}$ for soil moisture determinations.

During each wet and dry infiltration trial, a $900-\mathrm{ml}$ sample of the runoff was taken to determine sediment production. Samples were transported to the laboratory in nalgene containers, filtered through \#41 Whatman filter paper, and oven dried at $105^{\circ} \mathrm{C}$ for $24 \mathrm{hr}$.

After wet runs a $0.25 \mathrm{~m}^{2}$ quadrat was placed on each plot, and standing biomass was clipped at ground level and litter collected from the soil surface. Plant material was oven dried at $105^{\circ} \mathrm{C}$ for $24 \mathrm{hr}$. A steel probe was driven to bedrock at random locations within each plot to determine an average soil depth. Ocular estimates were made of percentage rock cover (Daubenmire 1959), slope, and microdepression numbers, size, and depth.

All data were analyzed using the Statistical Analysis System (Barr and Goodnight 1972). All variables were tested for skewness and kurtosis. Soil organic matter values were transformed to square roots and sediment values to logarithms. Stepwise multiple-regressions were used to determine variables associated with terminal infiltration rates and sediment production.

\section{Soil and Vegetation}

\section{Results}

All soils were sandy clay loams. Particle density means were similar at approximately $2.50 \mathrm{~g} / \mathrm{cc}$. Bulk density of soils from the heavy continuous pasture and the 4-pasture system were similar, but the exclosure had lower bulk densities. There was a trend of decreased pore space with increased grazing pressure. Percent organic matter of the two grazed pastures was lower than that of the exclosure; but all soils had relatively high organic matter, and comparable values were obtained with chemical and ashing methods of analysis. Soil aggregates were very stable and all samples rated 1 (Ashcroft 1954). Soil moistures for the grazed pastures were similar, while high values for the exclosures were due to over $25 \mathrm{~cm}$ of precipitation just prior to infiltration trials. Three categories of phytomass were approximately twice as great in the 4-pasture system and the exclosure as compared to the heavy continuous pasture (Table 1).

\section{Infiltration}

Infiltration data are presented for only wet runs (field
Table 1. Soil and Vegetation variables for the three study pastures.

\section{Pasture}

\begin{tabular}{|c|c|c|c|}
\hline Variable & Heavy continous & 4-pasture & Exclosure \\
\hline ulk density & & & \\
\hline $\begin{array}{l}(\mathrm{g} / \mathrm{cc}) \\
\text { ore space }\end{array}$ & $1.28 \pm .12^{1}$ & $1.23 \pm .09$ & $1.16 \pm .07$ \\
\hline$(\%)$ & $48.6 \pm 4.7$ & $50.9 \pm 3.5$ & $53.7 \pm 2.9$ \\
\hline $\begin{array}{l}\text { Prganic matter } \\
(\%)\end{array}$ & $5.32 \pm .65$ & $5.26 \pm 1.02$ & $5.76 \pm .41$ \\
\hline $\begin{array}{l}\text { (dry) }(\%) \\
\text { oil moisture }\end{array}$ & $19.7 \pm 6.5$ & $18.6 \pm 6.9$ & $42.6 \pm 5.9$ \\
\hline $\begin{array}{l}\text { oil moisture } \\
\text { (wet) }(\%) \\
\text { tanding phytomass }\end{array}$ & $31.9 \pm 3.8$ & $33.3 \pm 3.4$ & $47.4 \pm 6.0$ \\
\hline $\begin{array}{l}(\mathrm{kg} / \mathrm{ha}) \\
\text { itter phytomass }\end{array}$ & $1270 \pm 508$ & $2257 \pm 1235$ & $1907 \pm 811$ \\
\hline $\begin{array}{l}(\mathrm{kg} / \mathrm{ha}) \\
\text { otal phytomass }\end{array}$ & $1188 \pm 594$ & $2758 \pm 1601$ & $3031 \pm 2338$ \\
\hline$(\mathrm{kg} / \mathrm{ha})$ & $2458 \pm 869$ & $5016 \pm 2507$ & $4939 \pm 2618$ \\
\hline
\end{tabular}

'Mean and standard deviation.

capacity). Dry run (antecedent moisture) infiltration curves were similar to wet runs; however, terminal infiltration rates were 1 to $4 \mathrm{~cm} / \mathrm{hr}$ greater for dry runs. Most plots reached terminal infiltration midway through the 1-hr test (Fig. 1). Infiltration was similar for sites in the 4-pasture system and the exclosure while sites in the heavy continuous pasture were always lower than on corresponding sites in other pastures. When infiltration rate was averaged by site, deep sites had the highest values, followed by intermediate and shallow sites (Fig. 2 ). Infiltration rates averaged by pasture showed the exclosure and 4-pasture system to have almost identical curves and terminal infiltration values, while both had greater than twice the terminal infiltration rate of the heavy continuous pasture (Fig. 3).

Stepwise multiple-regressions were used to determine variables associated with terminal infiltration rates by sites and pastures and combined across all pastures and sites. Variables that were significant in at least one equation included: \% soil moisture wet (SMw), $\mathrm{kg} / \mathrm{ha}$ litter phytomass (LP), $\mathrm{kg} / \mathrm{ha}$ total standing phytomass (TP), cm soil depth (SD), \% rock cover (RC), number of depressions (ND), and g/cc bulk density (BD). Regression equations and results are presented for only wet runs, except in the combined analysis, since similar variables and $R^{2}$ values were obtained for equations of both dry and wet runs.

By site, litter phytomass, bulk density, and number of depressions were important variables in the infiltration regression equations (Table 2). On shallow sites with low vegetation production, variation in soil characteristics accounted for a greater proportion of the variation in infiltration, while on deeper soils phytomass exerted more influence over infiltration rate.

By pasture, litter phytomass and bulk density showed the greatest degree of association with infiltration rate in the heavy continuous pasture $\left(R^{2}=0.37\right)$. Number of depressions was the most important variable for wet runs in the 4-pasture system, with total phytomass and rock cover also appearing in the equation $\left(R^{2}=0.48\right)$. Soil depth in the exclosure had the greatest influence on infiltration, followed by litter and number of depressions $\left(R^{2}=0.52\right)$ (Table 2$)$.

Stepwise multiple regressions were used in a combined analysis to determine correlated factors with infiltration across 
Table 2. Multiple-regression equations for infiltration rate and sediment production at field capacity soil moisture by site and pasture.

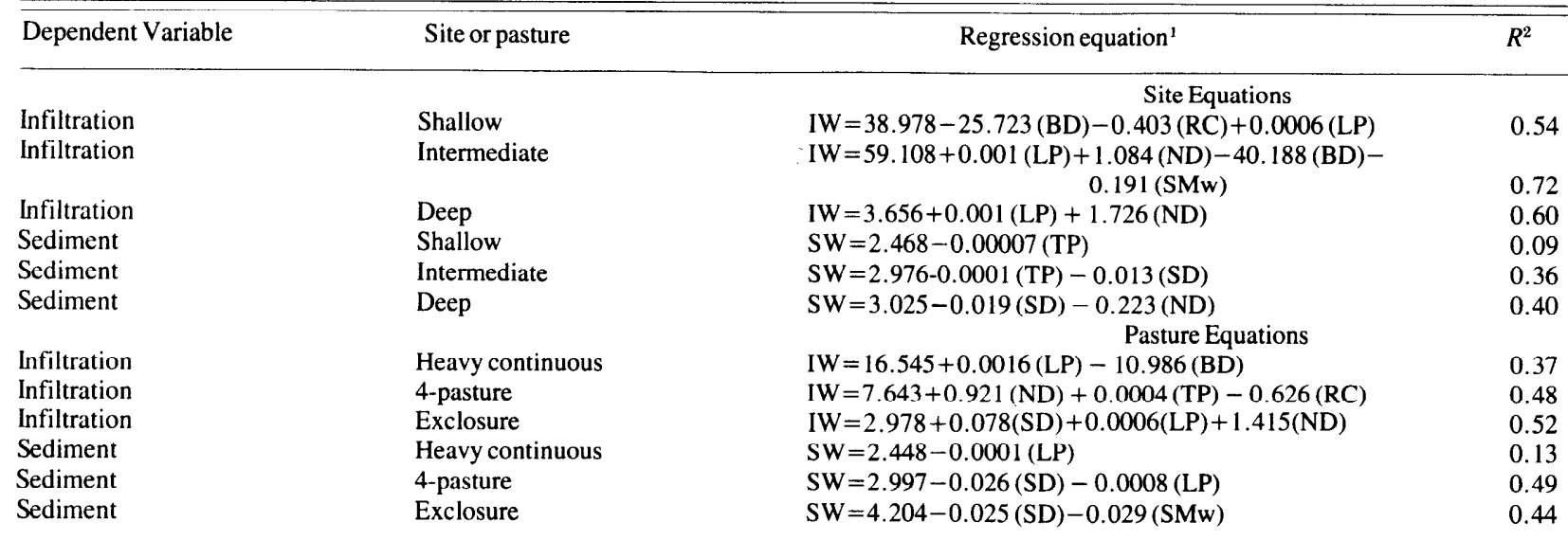

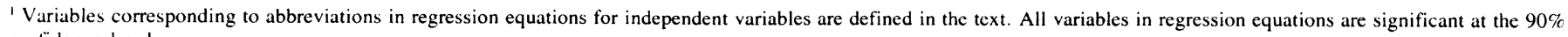
confidence level.

Table 3. Multiple-regression equations for infiltration rate and sediment production combined across pastures and sites at antecedent and field capacity soil moisture.

\begin{tabular}{|c|c|c|}
\hline Dependent variable & Regression equation ${ }^{1}$ & $R^{2}$ \\
\hline \multicolumn{3}{|l|}{ Infiltration } \\
\hline (antecedent) & $\mathrm{ID}=31.842+0.006(\mathrm{TP})-21.387(\mathrm{BD})+1.283(\mathrm{ND})$ & 0.58 \\
\hline \multicolumn{3}{|c|}{ (1) } \\
\hline (field capacity) & $\mathrm{IW}=23.053+0.0001(\mathrm{TP})+1.661(\mathrm{ND})-16.517(\mathrm{BD})$ & 0.62 \\
\hline \multicolumn{3}{|c|}{ 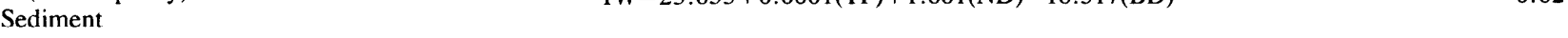 } \\
\hline (antecedent) & $\mathrm{SD}=2.833-0.0001(\mathrm{LP})-0.232(\mathrm{ND})-0.101(\mathrm{SD})$ & 0.46 \\
\hline \multicolumn{3}{|c|}{, } \\
\hline (field capacity) & $S W=2.852-0.012(\mathrm{SD})-0.0007(\mathrm{TP})-0.107(\mathrm{ND})$ & 0.42 \\
\hline
\end{tabular}

all pastures and sites. The equation accounted for $58 \%$ of the variation for dry runs with total phytomass and bulk density as the most important variables. Total phytomass, number of depressions, and bulk density accounted for $62 \%$ of the variation in infiltration rate during wet runs (Table 3 ).

\section{Sediment Production}

Sediment production values are described for only the wet runs; similar results were obtained for dry runs. Sediment production for the three pastures was similar for shallow and intermediate sites (Table 4). On deep sites, the exclosure and 4-pasture system were similar, although both produced approximately one-fourth as much sediment as the heavy continuous pasture. The exclosure and 4-pasture system tended to produce less sediment as soil depth increased. High sediment loss from deep sites in the heavy continuous pasture was probably due to

Table 4. Sediment production $(\mathrm{kg} / \mathrm{ha}$ ) at field capacity soil moisture for shallow, intermediate, and deep sites within three pastures (heavy continuous, 4-pasture system and exclosure).

\begin{tabular}{lcccl}
\hline \hline \multicolumn{1}{c}{ Site } & $\begin{array}{l}\text { Heavy } \\
\text { continuous }\end{array}$ & 4-pasture & Exclosure & Mean \\
\hline Shallow & $236 \pm 125^{1}$ & $184 \pm 191$ & $274 \pm 211$ & $231 \pm 179$ \\
Intermediate & $180 \pm 135$ & $171 \pm 110$ & $147 \pm 149$ & $166 \pm 130$ \\
Deep & $219 \pm 141$ & $49 \pm 65$ & $59 \pm 79$ & $109 \pm 126$ \\
Mean & $211 \pm 132$ & $134 \pm 143$ & $160 \pm 177$ & \\
\hline
\end{tabular}

${ }^{1}$ Mean and standard deviation. low vegetation cover compared to deep sites in the other pastures.

The heavy continuous pasture had the greatest sediment production followed by the exclosure and the 4-pasture system. Shallow sites had the greatest sediment loss, while deep sites had less than half as much sediment production (Table 4).

Stepwise multiple-regression equations were generated to define variables which related to sediment production within sites (Table 2). Only wet runs are presented except for the combined analysis. The only variable related to sediment production on shallow sites for wet runs was total phytomass $\left(R^{2}=0.09\right)$. On intermediate sites total phytomass and soil depth were important variables $\left(R^{2}=0.36\right)$, while on deep sites soil depth and number of depressions accounted for $40 \%$ of the variation.

When stepwise multiple regressions were calculated for each pasture, litter phytomass was the most important variable for the heavy continuous pasture $\left(R^{2}=0.13\right)($ Table 2$)$. In the 4-pasture system, soil depth was highly associated with sediment production with litter phytomass of less importance $\left(R^{2}=0.49\right)$. In the exclosure soil depth was the most important variable, followed by field capacity soil moisture $\left(R^{2}=0.44\right)$.

In the combined analysis for dry runs, the regression equation accounted for $46 \%$ of the variation in sediment production with litter the most important variable, followed by number of depressions and soil depth. For wet runs, soil depth was the most important and total phytomass and depression numbers of lesser importance. These factors accounted for $42 \%$ of the variation in wet run sediment production (Table 3 ). 


\section{Discussion}

Grazing management affects water intake and sediment production by altering soil and vegetation variables. Rangeland under heavy, continuous grazing had lower infiltration rates and higher sediment loss than rangeland under the 4-pasture deferred-rotation grazing system or the livestock exclosure. Infiltration rate and sediment production differences between pastures were generally related to differences in plant biomass, bulk density, depression storage, and soil depth. Decreased infiltration and increased erosion have been shown to be related to increased grazing intensity, particularly under continuous grazing (Dunford 1949; Johnston 1962; Rauzi and Hanson 1966). The impact of deferred-rotation grazing has not, however, been adequately evaluated.

Prior to establishment of the three study pastures in 1948, they had been subjected to longterm heavy, continuous grazing. At the time of this study, 27 years later, the exclosure and the deferred-rotation pasture had improved greatly in range condition (Smeins et al. 1975; Reardon and Merrill 1976). The two pastures also had similar and favorable hydrologic properties (Fig. 3 and Table 4). Improvement of range condition and hydrologic properties in the 4-pasture system cannot be attributed solely to the deferred-rotation grazing system. From 1948 to 1969 the pasture had been under continuous, moderate grazing and some improvement took place under those conditions. This study has shown that the deferred-rotation system maintained and possibly continued to improve range and hydrologic conditions. This relationship is true even though the stocking rate of the 4-pasture deferred-rotation pasture $(5.2$ $\mathrm{ha} / \mathrm{AU}$ ) and the heavy, continuous pasture (4.6-5.4 ha/AU) are nearly equal. Thus, it appears that deferred-rotational grazing can contribute to the maintenance, and possibily the improvement, of range condition and hydrologic conditions compared to heavy continuous grazing on Edwards Plateau rangeland.

\section{Literature Cited}

Ashcroft, G.L. 1954. Soil additives and their effect on the yield of various crops and the physical properties of an agricultural soil. MS Thesis. Utah State Univ. Logan. 88 p.
Barr, A.J., and J.H. Goodnight. 1972. A Users Guide to the Statistical Analysis System. N. Carolina State Univ. Press. Raleigh. 259 p.

Blackburn, W.H., R.O. Meeuwig, and C.M. Skau. 1974. A mobile infiltrometer for use on rangeland. J. Range Manage. 27:322-323.

Branson, F.A., F.G. Gifford, and J.R. Owen. 1972. Rangeland Hydrology. Soc. for Range Manage. $84 \mathrm{p}$.

Broadbent, F.E. 1965. Organic matter, p. 1397-1400. In: C.A. Black, Ed. Methods of Soil Analysis. Amer. Soc. Agron., Inc., Madison, Wisc. 1,572 p.

Carter, W.T., E.E. Templin, and I.C. Mowerg. 1938. Soil survey report of the Texas Range Station. Unpub. Rep.

Coleman, E.A. 1953. Vegetation and Watershed Management. Ronald Press Co. New York, N.Y. 412 p.

Daubenmire, R. 1959. A canopy-coverage method of vegetational analysis Northwest Sci. 33:43-64.

Davies, B.E. 1974. Loss-on ignition as an estimate of soil organic matter. Soil Sci. Soc. Amer. Proc. 38:150-151.

Day, P.R. 1956. Report of the committee on physical analysis. Soil Sci. Soc. Amer. Proc. 21:662.

Dunford, E.G. 1949. Relation of grazing to runoff and erosion on bunchgrass ranges. U.S. Forest Serv. Rocky Mt. Forest and Range Exp. Sta. Res. Note 7. $2 \mathrm{p}$.

Godfrey, C.L., C.R. Carter, and G.S. McKee. 1970. Land resource areas of Texas. Tex. Agr. Ext. Serv., Tex. Agr. Exp. Sta. Bull. 1070. 10 p.

Hardy, W.T., L.B. Merrill, C.W. Livingston, J.W. Menzies, and P.L. Huss. 1962. Agricultural Research in Texas. Tex. Agr. Prog. 8:17-20.

Johnston, A.F. 1962. Effects of grazing intensity and cover on the waterintake rate of fescue grassland. J. Range Manage. 15:79-82.

Long, A.T. 1962. Ground water geology of Edwards County. Tex. Water Levelop. Board Bull. 6208. $128 \mathrm{p}$

Lusby, G.C. 1970. Hydrologic and biotic effects of grazing vs. nongrazing near Grand Junction, Colorado. J. Range Manage. 23:256-260.

Merrill, L.B. 1954. A variation of deferred rotation grazing for use under Southwest range conditions. J. Range Manage. 7:152-154.

Rauzi, F., and C.L. Hanson. 1966. Water intake and runoff as affected by intensity of grazing. J. Range Manage. 19:351-355.

Reardon, P.O., and L.B. Merrill. 1976. Vegetative response under various grazing management systems in the Edwards Plateau. J. Range Manage 29:195-198.

Rhoades, E.E., L.F. Locke, H.M. Taylor, and E.H. McIlvain. 1964. Water intake on a sandy range as affected by 20 years of differential cattle stocking rates. J. Range Manage. 17:185-189.

Smeins, F.E., T.W. Taylor, and L.B. Merrill. 1975. Vegetation of a 25-year exclosure on the Edwards Plateau, Texas. J. Range Manage. 29:24-29.

Vormocil, J.A. 1965. Pore space. p. 299-300. In: C.A. Black, Ed. Methods of Soil Analysis. Amer. Soc. Agron., Inc., Madison, Wisc. 1,572 p.

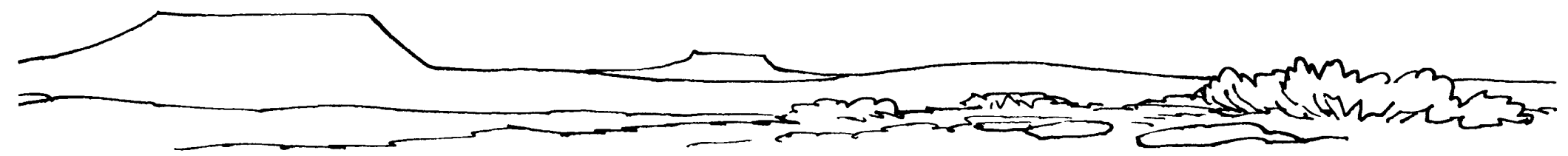

